producing a true blueprint for optimum growth and how well the new charts actually fit to the growth of infants in the United Kingdom.

If they pass the test, for the first time infants worldwide could be compared with the same growth standard, with breast fed infants rightly established as the norm with which all other infants should be compared.

\section{Charlotte M Wright senior lecturer}

Department of Child Health, Glasgow University PEACH Unit, OMH Tower, Yorkhill Hospitals, Glasgow G3 8SJ

(charlotte.wright@clinmed.gla.ac.uk)

Competing interests: CW has published a specialist growth chart based on the United Kingdom 1990 growth reference.

1 Tanner J, Whitehouse R, Takaishi M. Standards from birth to maturity for height weight height velocity and weight velocity: British children 1965 Part I. Arch Dis Child 1966;41:454-71.

2 National Center for Health Statistics (NCHS). NCHS growth curves for children birth-18 years, United States. Washington DC: US Department of children birth-18 years, United States. Washington DC: US Department of no 165) (DHEW publication no (PHS) 78-1650).
3 Whitehead RG, Paul AA. Growth charts and the assessment of infant feeding practices in the Western world and in developing countries. Early Hum Dev 1984:9:187-207.

4 Freeman JV, Cole TJ, Chinn S, Jones PRM, White EM, Preece MA. Cross sectional stature and weight reference curves for the UK, 1990. Arch Dis Child 1995;73:17-24

5 Wright C, Corbett S, Drewett R. Sex differences in weight in infancy and the British 1990 growth standards. BMJ 1996;313:513-4.

6 Kuczmarski RJ, Ogden CL, Guo SS, Grummer-Strawn LM, Flegal KM, Mei Z, et al. 2000 CDC growth charts for the United States: methods and development. National Center for Health Statistics. Vital Health Statistic 2002;11.

7 Wright CM, Parkinson KN. Postnatal weight loss in term infants: what is normal and do growth charts allow for it? Arch Dis Child Fetal Neonatal Ed 2004:89:F254-7.

8 Savage S, Reilly J, Durnin J. Weight and length of Glasgow infants compared to Tanner and Whitehouse standards and new British standards for growth. Proceed Nutr Soc 1996;55:81A.

9 Wright C, Booth I, Buckler J, Cameron N, Cole T, Healy M, et al. Growth reference charts for use in the United Kingdom. Arch Dis Child 2002;86:11-4.

10 de Onis M, Garza C, Victora CG, Onyango AW, Frongillo EA, Martines J. The WHO Multicentre Growth Reference Study: planning, study design, and methodology. Food Nutr Bull 2004;25:s15-26.

11 Cole TJ, Paul AA, Whitehead RG. Weight reference charts for British long-term breastfed infants. Acta Paediatr 2002;91:1296-300.

12 Kramer MS, Guo T, Platt RW, Shapiro S, Collet JP, Chalmers B, et al. Breastfeeding and infant growth: biology or bias? Pediatrics 2002;110:343-7.

\title{
Strontium ranelate for the treatment of osteoporosis
}

\author{
Is useful, but changes in bone mineral density need careful interpretation
}

$\mathrm{T}$ The successful treatment of osteoporosis is a relatively recent phenomenon. Although bisphosphonates are now established as the treatment of choice, ${ }^{1}$ this only came about with the publication in 1996 of the FIT alendronate trial. ${ }^{2}$ Nowadays the main treatment options are anti-resorptive agents that prevent bone breakdown. Most studies of these agents show good protection against fractures of the spine, while the more potent nitrogen containing bisphosphonates also show a reduction in non-vertebral fractures. ${ }^{1-5}$ For patients with previous fractures, treatment with an anabolic agent that enhances bone formation is clearly preferable, and this is now possible since the introduction of 1-34 recombinant parathyroid hormone (PTH). ${ }^{6}$ However, the use of PTH is limited by its high cost and the need for subcutaneous self injection. Recently strontium ranelate has been licensed in the United Kingdom for the treatment of osteoporosis. Here we draw attention to the unusual effect of strontium treatment on bone mineral density and discuss the potential bonus that this effect can be used for assessing adherence to therapy.

The mechanism of action of strontium ranelate is not yet fully understood, compared with other treatments, but it seems to have a unique effect in that it inhibits bone resorption as well as stimulating bone formation. ${ }^{7}$ Recent studies, the SOTI and TROPOS trials, have shown its efficacy at preventing both vertebral and non-vertebral fractures, ${ }^{78}$ including hip fractures in older women. ${ }^{8}$ Strontium ranelate was well tolerated in these trials without any major side effects. The most common side effects reported were a small increase in the incidence of nausea and diarrhoea.

Strontium ranelate is composed of two atoms of stable strontium combined with organic ranelic acid. The ranelic acid is a carrier that makes the treatment palatable, and the strontium is the active component with regard to the skeleton. As an alkaline earth element, strontium is similar to calcium in its absorption in the gut, incorporation in bone, and elimination from the body through the kidneys. ${ }^{9}$ Strontium is naturally present in trace amounts with around $100 \mu \mathrm{g}$ in every gram of bone, ${ }^{\mathrm{w1}}$ so treatment with strontium ranelate is simply making more strontium available for incorporation into bone. In the short term the strontium atoms are adsorbed on to the surface of hydroxyapatite crystals, and in the longer term some strontium will exchange with calcium in the bone mineral and may remain bound in the skeleton for years. ${ }^{9}$ Strontium not incorporated into bone is excreted through the kidneys and faeces. After three years' treatment with strontium ranelate, bone tissue will contain around one strontium atom for every 100 calcium atoms. In animal studies, up to one calcium atom in 10 was substituted with strontium without any important modifications of bone mineral at the crystal level. ${ }^{10}$ No human studies have yet reported how quickly bone strontium is washed out once treatment is stopped. However, studies with radioactive strontium show that much of the stable strontium present in bone after three years of treatment will still be there a decade later.

What are the changes in bone mineral density with strontium ranelate? In the SOTI trial, an impressive increase in bone mineral density occurred in the spine (14.4\%) and hip (8.3\%). ${ }^{7}$ However, some caution is necessary in interpreting these figures because much of this effect is due to the higher atomic number of strontium $(\mathrm{Z}=38)$ compared with calcium $(\mathrm{Z}=20)$. When bone mineral density is measured by bone densitometry, atom for atom strontium attenuates $\mathrm{x}$ rays more strongly than calcium. As a result a $1 \%$ molar fraction of

Additional references w1-w5 are on bmj.com 
strontium causes a $10 \%$ overestimation of bone mineral density. ${ }^{11}$ In the SOTI trial, bone biopsy was performed in a subset of patients and the data for bone mineral density corrected on the basis of the correlation between the bone strontium content measured in the biopsy samples and concentrations of strontium in the blood. After the adjustment for bone strontium, the measured effect of treatment on bone mineral density in the spine of $14.4 \%$ was corrected to $8.1 \%{ }^{7}$

The important issue for treatment for osteoporosis is prevention of fractures and not changes in bone mineral density. This lesson was learnt with fluoride therapy, which led to dramatic increases in bone mineral density of the spine but in higher dosage caused an increased incidence of hip fracture. ${ }^{12}$ Caution is therefore needed in predicting efficacy against fractures simply on the basis of a change in bone mineral density.

Although measurements of bone mineral density are of value in diagnosing osteoporosis and in assessing the risk of fracture, ${ }^{\text {w2 }}{ }^{\text {w3 }}$ many believe that they are of limited use in monitoring treatment. An increase of 5\% in spine bone mineral density is required to confirm a

1 Cranney A, Guyatt G, Griffith L, Wells G, Tugwell P, Rosen C. Summary of meta-analyses of therapies for postmenopausal osteporosis. Endocrin Rev 2002;23:570-8.

2 Black DM, Cummings SR, Karpf DB, Cauley JA, Thompson DE, Nevitt $\mathrm{MC}$, et al. Randomised trial of the effect of alendronate on risk of fracture in women with existing vertebral fractures. Lancet 1996;348:1535-41.

3 Cummings SR, Black DM, Thompson DE, Applegate WB, BarrettConnor E, Musliner TA, et al. Effect of alendronate on risk of fracture in Connor E, Musliner TA, et al. Effect of alendronate on risk of fracture in
women with low bone density but without vertebral fractures: results women with low bone density but without vertebral fractu
from the fracture intervention trial. JAMA 1998;280:2077-82.

4 Harris ST, Watts NB, Genant HK, McKeever CD, Hangartner T, Keller M, et al. Effects of risedronate treatment on vertebral and non-vertebral fractures in women with postmenopausal osteoporosis. JAMA 1999;282: 1344-52.

5 McClung MR, Geusens P, Miller PD, Zippel H, Bensen WG, Roux C, et al Effect of risedronate treatment on hip fracture risk in elderly women. $N$ Engl J Med 2001;344:333-40.

6 Neer RM, Arnaud CD, Zanchetta JR, Prince R, Gaich GA, Reginster J-Y et al. Effect of parathyroid hormone (1-34) on fractures and bone mineral density in postmenopausal women with osteoporosis. N Engl J Med 2001; density in pos $344: 1434-41$.

7 Meunier PJ, Roux C, Seeman E, Ortolani S, Badurski JE, Spector TD, et al. The effects of strontium ranelate on the risk of vertebral fracture in notable response to treatment. ${ }^{\mathrm{w}}$ Often the changes are smaller than this, and as a result measurements of bone mineral density to monitor treatment are carried out only after two years..$^{\mathrm{w}}$ With strontium ranelate, large increases in bone mineral density are often seen, and if this is the case one can be confident that the patient is complying with treatment. Though changes in bone mineral density measured during treatment with strontium are somewhat artefactual, they might still prove clinically useful. The issue of patients' long term use and compliance with treatment is important for all types of treatment for osteoporosis. For strontium ranelate, the large increase in bone density expected by 12 months may prove useful in this regard and could provide reassurance for the patient and the clinician.

Ignac Fogelman professor

Department of Nuclear Medicine, Guy's Hospital, London SE1 9RT (ignac.fogelman@kcl.ac.uk)

Glen M Blake senior lecturer

Guy's, King's, and St Thomas' School of Medicine, London SE1 9RT

Competing interests: IF has acted as a consultant to Servier, manufacturer of strontium ranelate.

women with postmenopausal osteoporosis. $N$ Engl J Med 2004;350: $459-68$.

8 Reginster JY, Seeman E, De Vernejoul MC, Adami S, Compston J, Phenekos C, et al. Strontium ranelate reduces the risk of nonvertebral fractures in postmenopausal women with osteoporosis: TROPOS study J Clin Endocrinol Metab 2005. (Published online 22 Feb; doi:10.1210/ jc.2004-1774.)

9 Marshall JH, Lloyd EL, Rundo J, Liniecki J, Marotti G, Mays CW, et al. Marshall JH, Lloyd EL, Rundo J, Liniecki J, Marotti G, Mays CW, et al.
Alkaline earth metabolism in adult man. A report prepared by a task group of committee 2 of the International Commission on Radiological Protection (ICRP publication 20). Health Phys 1973;24:129-221.

10 Boivin G, Deloffre P, Perrat B, Panczer G, Boudeulle M, Mauras Y, et al Strontium distribution and interactions with bone mineral in monkey iliac bone after strontium salt administration (S12911).J Bone Miner Res 1996;11:1302-11

11 Pors Nielsen S, Slosman D, Sorensen OH, Basse-Cathelinat B, De Casin P, Roux C, et al. Influence of strontium on bone mineral density and bone mineral content measurements by dual x-ray absorptiometry. J Clin Densitom 1999;2:371-9.

12 Riggs BL, Hodgson SF, O'Fallan M, Chao EYS, Wahner HW, Muhs JM, et al. Effect of fluoride treatment on the fracture rate in postmenopausal women with osteoporosis. N Engl J Med 1990;322:802-9.

\section{Reducing variation in surgical care}

\section{Requires innovative methods for getting evidence into surgical practice}

Papers p 1420

BMJ 2005;330:1401-2
$\mathrm{V}$

ariations in surgical care have been recognised since the early 1980 s and are generally interpreted as evidence of uncertainty among practitioners regarding optimal care. The prescription for remedying variations in surgical practice has generally included development of better medical evidence to identify best practices, dissemination of medical evidence to surgeons, and use of practice guidelines and care pathways to streamline care. More than 20 years later, there is still abundant evidence that surgical care varies substantially. Why do variations in surgical care persist? And what can be done about them?

In this issue of $B M J$, Lassen et al (p 1420) report the results of a survey of lead surgeons in five north European countries regarding processes of care for colorectal surgery. ${ }^{1}$ These processes included use of preoperative bowel preparation, routine postoperative nasogastric decompression, and use of epidural analgesia in the postoperative surgical ward. The survey identified substantial international variation in the use of such perioperative interventions. In many cases, this variation occurred in spite of abundant, high quality medical evidence.

Surgery and evidence based medicine have had turbulent relations of late. There is broad recognition that much of current surgical practice is not informed by solid medical evidence ${ }^{2}$ and that the application of methods such as randomised controlled trials to surgical questions is often difficult or impractical. ${ }^{3}$ However, there is growing uniformity of opinion in the surgical community that the quality of evidence supporting surgical care must be improved and that we need innovative methods for disseminating evidence into practice. $^{4}$ 